GRADIATION\&APPLICATIONS

ISSN 2466-4294 (online) | rad-journal.org

Vol. 2 | Issue 2 | pp. 108 - 114, 2017

doi: 10.21175/RadJ.2017.02.023

Original research paper

\title{
MEASUREMENTS OF LEAD-210 ACTIVITY CONCENTRATION IN THE GROUND-LEVEL AIR IN FINLAND AND BULGARIA*
}

\author{
Jussi Paatero', Blagorodka Veleva ${ }^{2 * *}$, Elena Hristova² ${ }^{2}$ Juha Hatakka1
}

${ }^{1}$ Finnish Meteorological Institute, Helsinki, Finland

${ }^{2}$ National Institute of Meteorology and Hydrology, Sofia, Bulgaria

\begin{abstract}
Airborne lead-210 is a useful tracer for studying air mass origin and transport. ${ }^{210} \mathrm{~Pb}$ is produced in the atmosphere by the decay of the radioactive noble gas ${ }^{222} \mathrm{Rn}$, emanating after ${ }^{226} \mathrm{Ra}$ decay from the earth crust. The results obtained for ${ }^{210} \mathrm{~Pb}$ concentration in total suspended particulate (TSP) display seasonal pattern with maximum in the summer-autumn period. The TSP filters are collected within the scope of atmospheric radioactivity monitoring in NIMH, Bulgaria and were measured initially for short and long lived beta radionuclides. The methodology developed in FMI, Finland, based on gross alpha counting of ${ }^{210} \mathrm{Po}-$ the daughter of the combined aerosol filters samples collected in Sofia during the period $2001-2003$ and 2006-2007, is applied. The first results for $210 \mathrm{~Pb}$ in particulate matter, fraction below $10 \mu \mathrm{m}\left(P M_{10}\right)$, in February 2012 in Sofia are presented. The alpha counting methodology was successfully applied for daily PM1O quartz filters with the counting uncertainty value of $\leq 20 \%$. Lead-210 daily concentration is compared to the PM 10 mass concentration and elemental lead concentration, determined by EDXRF technique. The comparison between ${ }^{210} \mathrm{~Pb}$, elemental lead and PM 10 mass concentration reveals a different time variation for days with cyclonic weather and mass transport from south-west and an anticyclone episode with increasing PM $M_{10}$, lead-210 and lead concentrations from day to day. An increase in the $P M_{10} /{ }^{210} \mathrm{~Pb}$ ratio indicates local sources of the particulate mass.
\end{abstract}

Key words: Atmospheric radioactivity, Bulgaria, Finland, Lead-21o tracer, PM1o

\section{INTRODUCTION}

Lead-210 is produced in the atmosphere by the decay of the radioactive noble gas radon-222. ${ }^{222} \mathrm{Rn}$ is emanating from the earth surface to the atmosphere after the decay of its parent ${ }^{226} \mathrm{Ra}$. The concentration of ${ }^{222} \mathrm{Rn}$ and its daughters in the surface air layer depends on the exhalation rate, proportional to the ${ }^{226} \mathrm{Ra}$ concentration in the soil, soil structure, soil moisture, snow cover, etc. [1]. Because of the low ${ }^{226} \mathrm{Ra}$ content in the surface waters, ${ }^{222} \mathrm{Rn}$ emanation rates from the continent are about two orders of magnitude higher than that of the ocean. [2]. The practically exclusive formation mechanism of airborne ${ }^{210} \mathrm{~Pb}$ facilitates its use as a tracer for air masses with a continental or maritime origin in the polar region [3] and the Southwestern region of Spain [4].

Radon in the air, being a noble gas, exists as single atoms. Its short lived daughters are rapidly attached to the aerosol particles, and ${ }^{210} \mathrm{~Pb}$ is found to be attached to the fine particulate matter and submicron particles [5]. Recently ${ }^{210} \mathrm{~Pb}$ variation in atmospheric fine particulate matter with the diameter of less than $10 \mu \mathrm{m}$, $\mathrm{PM}_{10}$, is collected because of its importance for air quality monitoring programs and is reported for some sites/regions. ${ }^{210} \mathrm{~Pb}$ together with some other natural radionuclides are recognized as useful tracers in the global monitoring network for the atmospheric composition of World Meteorological Organization (WMO) and that is why are measured at many stations of Global Atmospheric Watch (GAW) network [6].

The first results for the ${ }^{210} \mathrm{~Pb}$ concentration in $\mathrm{PM}_{10}$ in Sofia are discussed in the present paper. The results concerning the trends of ${ }^{210} \mathrm{~Pb}$ activity concentration in the total suspended particulate matter (TSP) in the ground-level air in Finland and Bulgaria, reported in [7] are expanded here with the additional data for four more years.

The national weather services in both Finland and Bulgaria responded in the late 1950 s to the imminent need for monitoring of airborne radioactivity caused by the intense testing of nuclear weapons in the atmosphere. Soon both institutes, the Finnish Meteorological Institute (FMI) in Finland and the National Institute of Meteorology and Hydrology (NIMH) in Bulgaria, adapted monitoring methods for airborne total beta activity, because these methods are relatively simple and cost-efficient. Both institutes have been monitoring the total beta activity with daily

\footnotetext{
* The paper was presented at the Fifth International Conference on Radiation and Applications in Various Fields of Research (RAD 2017), Budva, Montenegro, 2017.

blagorodka.veleva@meteo.bg
} 
sampling. Five days after the end of sampling, the short-lived radon-222 daughter nuclides have decayed to lead-210 and radon-220 progeny has decayed to stable lead-208. In 1967 the FMI also started the monitoring of the daily activity concentration of lead210 in the air. The analysis is based on the alpha counting of the in-grown daughter nuclide polonium210 six months after the sampling.

\section{MATERIALS AND METHODS}

There are different methods to measure ${ }^{210} \mathrm{~Pb}$, based on it and its daughters' decay properties [8]. The decay of ${ }^{210} \mathrm{~Pb}$ is as follows:

${ }^{210} \mathrm{~Pb}(22.2 \mathrm{y}) \rightarrow{ }^{210} \mathrm{Bi}(5.01 \mathrm{~d}) \rightarrow{ }^{210} \mathrm{Po}(138.4 \mathrm{~d}) \rightarrow^{206} \mathrm{~Pb}$

Lead-210 decays by $\beta$ emission $\left(\mathrm{E}_{\beta \max }=17 \mathrm{keV}\right.$, branching ratio $\mathrm{BR}=80.2 \%$ and $\mathrm{E}_{\beta \max }=63.5 \mathrm{keV}$, $\mathrm{BR}=15 \%)$ followed by $\gamma$-radiation $(\mathrm{E} \gamma=46.5 \mathrm{keV}$, $4.25 \%)$. The ${ }^{210} \mathrm{~Pb}$ decay product ${ }^{210} \mathrm{Bi}$ is also a beta emitter with a much higher energy of beta radiation $\left(\mathrm{E}_{\beta \max }=1162 \mathrm{keV}, \mathrm{BR}=100 \%\right)$ than its parents: The resulting ${ }^{210} \mathrm{Po}$ is an alpha emitter $(\mathrm{Ea}=5304 \mathrm{keV}$, $\mathrm{BR}=100 \%$ ).

Beta radiometry is used initially to measure the total long lived beta $\left({ }^{210} \mathrm{~Pb}\right.$ and ${ }^{210} \mathrm{Bi}$ prevailingly) in the daily filters from NIMH. Then the composite half a month (14-16 days) sample is measured by FMI alpha/beta analyzer. ${ }^{210} \mathrm{Po}$ activity is measured several years after filters sampling, when the equilibrium with ${ }^{210} \mathrm{~Pb}$ is reached, but the initially collected ${ }^{210} \mathrm{Po}$ is decayed. The results are decay corrected. The blank filters sample is below the instrument's background.

In addition to gross alpha/beta counting the ${ }^{210} \mathrm{~Pb}$ concentration was measured directly by gamma spectrometry with N-type coaxial HPGe-detector Ortec GMX-45200-P with a $40 \%$ relative efficiency. Because of in principal lower efficiency and low emission probability, the detection limit in gamma spectrometry is higher and a larger sample is required. Two months composed samples from the period 2006-2007 were analyzed in counting geometry, developed for $r$ spectrometry of FMI filters. The MDA in these measurements vary from less than 0.05 to 0.16 mBq.m-3, depending on the measurement time $\left(2.5 \cdot 10^{5} \mathrm{~S}-15 \cdot 10^{5} \mathrm{~S}\right)$ and sample volume.

\subsection{Air particulate sampling and beta radiometry, Bulgaria}

The TSP aerosol samples were collected in Sofia $\left(42^{\circ} 39^{\prime} \mathrm{N}, 23^{\circ} 23^{\prime} \mathrm{E}\right.$, height $589 \mathrm{~m}$ above sea level, a.s.l), Bulgaria, at the National Institute of Meteorology and Hydrology (NIMH) at $2 \mathrm{~m}$ height above the grass surface on $35 \mathrm{~mm}$ nitrocellulose filters (Synpor-2;3) by a vacuum pump. Air volume was measured by a dry flow meter. The samples were changed every day at 6:00 GMT (8:00 Local Standard Time). Typical sample volume was in the range of $90-110 \mathrm{~m}_{3}$ per day. Beta activity of the TSP filter was measured by beta radiometers with thin plastic scintillators under the passive lead shielding. Detectors were regularly calibrated with a ${ }^{90} \mathrm{Sr}+{ }^{90} \mathrm{Y}$ source. The filters were measured at the $5^{\text {th }}$ minute after sampling for short lived beta activity, mainly due to the ${ }^{222} \mathrm{Rn}$ and ${ }^{220} \mathrm{Rn}$ daughter nuclides, and again after 72 and 120 hours for determination of the so-called "long lived" beta activity. The sampling, devices, and measurement algorithm remain unchanged since the 1980's. The particulate matter with $\mathrm{d}<10 \mu \mathrm{m}$, or $\mathrm{PM}_{10}$ is collected in experimental campaigns, in order to study $\mathrm{PM}_{10}$ mass concentration and elemental composition since 2012. The TECORA ECHO PM Low volume sampler and Whatman quartz filters were used [9].

\subsection{Air particulate sampling and analyses, Finland}

The Finnish Meteorological Institute has collected daily aerosol samples at the Nurmijärvi geophysical observatory $\left(60^{\circ} 30^{\prime} \mathrm{N}, 24^{\circ} 39^{\prime} \mathrm{E}\right.$, height $105 \mathrm{~m}$ a.s.l.) and at the Arctic Research Centre at Sodankylä $\left(67^{\circ} 22^{\prime} \mathrm{N}, 26^{\circ} 39^{\prime} \mathrm{E}\right.$, height $198 \mathrm{~m}$ a.s.l.) since the early

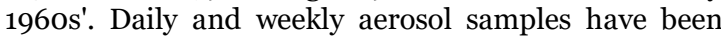
collected onto the glass fiber or paper filters at several stations. The total beta activities of the samples are measured five days after the end of sampling and after 6 months for measurement of $210 \mathrm{~Pb}$ by its daughter ${ }^{210}$ Po. The daily aerosol samples in Finland were collected onto the glass-fibre filters (Whatman GF/A or Munktell MGA, $\varnothing=24 \mathrm{~cm}$ ) using a high-volume sampler. The sampler has a capacity of $3500 \mathrm{~m} 3$ per day, and collects particles with an aerodynamic diameter of less than 10-15 $\mu \mathrm{m}$, depending on the wind speed. The filters were changed every morning at 06 UTC.

Since 1982 two successive automatic alpha/beta analyzers have been used [10], see Fig.1. The detector arrangement consists of five gas-flow proportional counters, three above the filter sample and two below it. The counter immediately above the filter is measuring alpha particles and the counter on top of it is measuring beta particles. The counter immediately below the sample is also sensitive to beta particles. The topmost and bottommost counters are enclosed in steel and they are used for anti-coincidence background suppression. The flow gas is a mixture of argon (90 \%) and methane (10\%). The measurement of ${ }^{210} \mathrm{~Pb}$ is based on the alpha counting of the in-grown daughter nuclide ${ }^{210} \mathrm{Po}$. The counting efficiency for ${ }^{210} \mathrm{Bi}$ (beta) is $75 \%$ and for ${ }^{210} \mathrm{Po}$ (alpha) $-42 \%$. Background samples and reference samples $\left({ }^{242} \mathrm{Pu},{ }^{0} \mathrm{Sr}\right.$ and $\left.{ }^{55 \mathrm{Fe}}\right)$ are measured in every counting series.

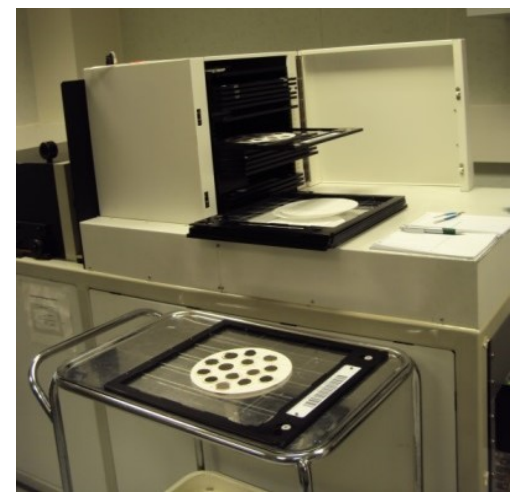

Figure 1. Low level alpha/beta analyzer in FMI with combined semimonthly filter samples from Sofia, NIMH 
Comparative assessment of the results of the monitoring programs in NIMH and FMI concerning global nuclear bomb fallout and long range transport of the Chernobyl releases are given, for example, in [11][12], where the collaboration between NIMH and FMI labs is described in more details. The traces of Fukushima NPP accidental releases in 2011 detected in both countries are discussed in [13].

\section{RESULTS AND DISCUSSION}

\subsection{Lead-21O concentration in TSP samples}

The mean monthly beta activity, measured $12 \mathrm{oh}$ after the sampling in Sofia for the 2000-2010 period is presented in Fig. 2. This period decades after Chernobyl and before Fukushima accidents is characterized with very low concentrations of technogenic long lived beta radionuclides in the air and is suitable for the application of the technique developed in FMI for ${ }^{210} \mathrm{~Pb}$ analyses. Because of its long half life time and aerosol residence time, ${ }^{210} \mathrm{~Pb}$ undergoes transport and removal processes. The most effective aerosol removal mechanism is rain-out and wash-out and wet deposition by precipitation. The precipitation in addition leads to higher soil moisture and decreased Radon exhalation rate. The attempt to estimate statistically the connection between the mean monthly "long lived" beta activity and monthly precipitation sum gives weak negative correlation: $r=-$ 0.14 for the years with the annual precipitation sum above the norm, and $\mathrm{r}=-0.08$ for the dry years (2000, 2004 and 2008).

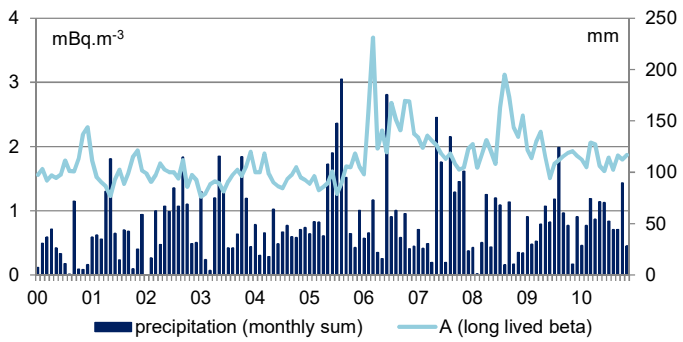

Figure 2. Mean monthly beta activity (A) and monthly precipitation sum in Sofia, during the period 2000-2010

Table 1. Mean annual concentration of ${ }^{210} \mathrm{~Pb}$, total beta and annual sum of precipitation in Sofia

\begin{tabular}{|l|c|l|l|}
\hline Year & $\begin{array}{l}\text { Precipitation } \\
\text { Annual sum, } \\
(\mathrm{mm})\end{array}$ & $\begin{array}{l}\mathrm{A}(\beta) \\
\left(\mathrm{mBq} \cdot \mathrm{m}^{-3}\right)\end{array}$ & $\begin{array}{l}{ }^{210} \mathrm{~Pb} \\
\left(\mu \mathrm{Bq} \cdot \mathrm{m}^{-3}\right)\end{array}$ \\
\hline 2001 & 535.1 & 2.66 & 263.94 \\
2002 & 646.7 & 2.39 & 230.39 \\
2003 & 678.1 & 2.24 & 174.10 \\
2004 & 534 & 2.39 & - \\
2005 & 970.7 & 2.30 & - \\
2006 & 634.1 & 3.80 & 220.72 \\
2007 & 809 & 3.60 & 227.40 \\
\hline
\end{tabular}

The positive correlation coefficient between ${ }^{210} \mathrm{~Pb}$ concentration and mean semimonthly gross beta, measured at $72 \mathrm{~h}$, is 0.58 for the period 2001-2003 and 0.64 (2006-2007). This correlation can be used to estimate ${ }^{210} \mathrm{~Pb}$ concentration based on total beta measurement.

Higher ${ }^{210} \mathrm{~Pb}$ concentrations during the warm period of the year (June -October) are observed for Sofia (Fig.3). The reason for that are higher temperatures and more dry soils enhancing ${ }^{222} \mathrm{Rn}$ emanation during this time of the year. Similar seasonal pattern with maximums during the warm season is reported for the Mediterranean coasts in [4] in Spain and at the GAW mountain station at Mt.Cimone in Italy [14]. The monthly variation of ${ }^{210} \mathrm{~Pb}$ in Serbia, reported in [15] for the period 2011-2012, show spring minimum, maximum in November followed by the low values for December and January. Specific seasonality is observed in Edinburg [16], with marked peaks in April during the years 2002-2003. The reported values are in the range of 0.01-0.74 $\mathrm{mBq} \cdot \mathrm{m}^{-3}$. This is different from Finland, where a winter maximum for Nurmijarvi is reported. Mean annual concentration during the period 2001-2007 varies in the range of $180-280 \mu B q . m^{-3}$ in Nurmijarvi and $170-$ $270 \mu \mathrm{Bq} . \mathrm{m}^{-3}$ in Sofia.

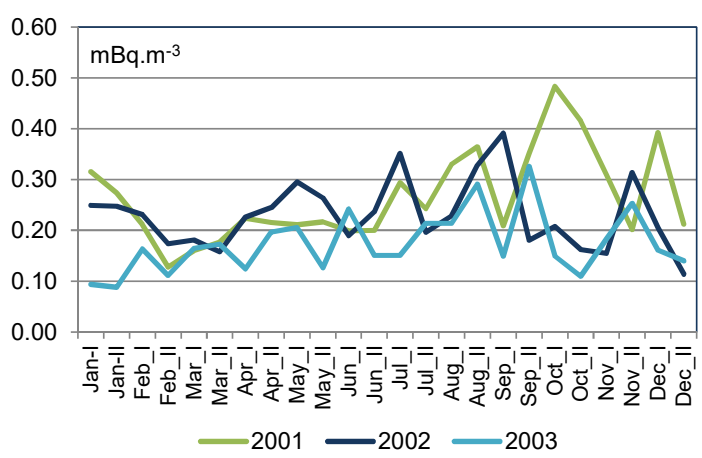

Figure 3. Lead-210 concentration in Sofia in semi-monthly samples, 2001-2003

The tendency of decrease in ${ }^{210} \mathrm{~Pb}$ concentration reported previously in [7] for the beginning of the 21st century is not followed during the years 2006-2007, Table 1.

It should be pointed out that the measured concentrations in Sofia TSP filters could be underestimated with $15-30 \%$, because the efficiency of the filter for the submicron fraction of $210 \mathrm{~Pb}$ might not be $100 \%$. This estimation is based on the comparative measurements of short lived ${ }^{222} \mathrm{Rn}$ daughters and ${ }^{212} \mathrm{~Pb}$ in TSP and PM10 filters during the experimental campaigns in 2012-2014. There is a seasonal difference in TSP filter efficiency for ${ }^{212} \mathrm{~Pb}\left({ }^{220} \mathrm{Rn}\right.$ daughter $)$, higher in summer than in winter.

The results obtained for Sofia by the two methods of measurements of ${ }^{210} \mathrm{~Pb}$ - gamma spectrometry and ${ }^{210}$ Po measurements by $\alpha / \beta$ analyzer, are compared in Fig. 4. The results show similar seasonal variation with the maximum during summer-autumn months. Higher uncertainty and less time resolution with few values 
below DL are seen for ${ }^{210} \mathrm{~Pb}$ concentrations, measured by $\curlyvee$-spectrometry.

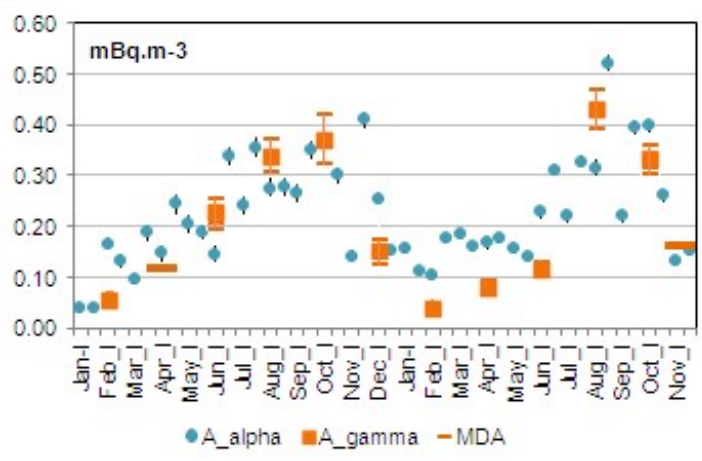

Figure 4. Lead-210 concentration and uncertainty: by $\alpha / \beta$ analyzer (A_alpha, semi-monthly) and by $\gamma$-spectrometry (A_gamma, and MDA of A_gamma) in Sofia, 2006- 2007

In addition, the effectiveness of ${ }^{210} \mathrm{~Pb}$ measurements is higher by $\alpha / \beta$ analyzer because of the shorter measurement time and automated sample change.

The variation of airborne ${ }^{210} \mathrm{~Pb}$ in Finland is presented in Fig.5 for the period 2000-2007 and the available mean annual values for Sofia are given. The ${ }^{210} \mathrm{~Pb}$ activity concentration in northern Finland is usually lower than in southern Finland. Compared to southern Finland, northern Finland is more often dominated by air masses coming from the North Atlantic Ocean and the Arctic Ocean with practically no radon, and thus no Lead-210 sources [17].

The year-to-year variation of ${ }^{210} \mathrm{~Pb}$ activity concentration in Finish station has been explained by the North Atlantic Oscillation (NAO) and the heat and salinity conditions of the northern seas [18]. Despite this variation, the long-term concentration level has been constant without any evident trends. However, there seems to be a sudden decrease in the concentration level in the turn of the 1980 s and 1990 s. Starting from the late 1980 , there seems to be a decreasing trend in the ${ }^{210} \mathrm{~Pb}$ activity concentration in the air. This downward trend becomes steeper towards south. Thus, in Sofia, on the $42^{\text {nd }}$ latitude, the downward trend is an order of the magnitude stronger than at Sodankylä on the $67^{\text {th }}$ latitude [7]. Similar behavior has been reported in Germany [19].

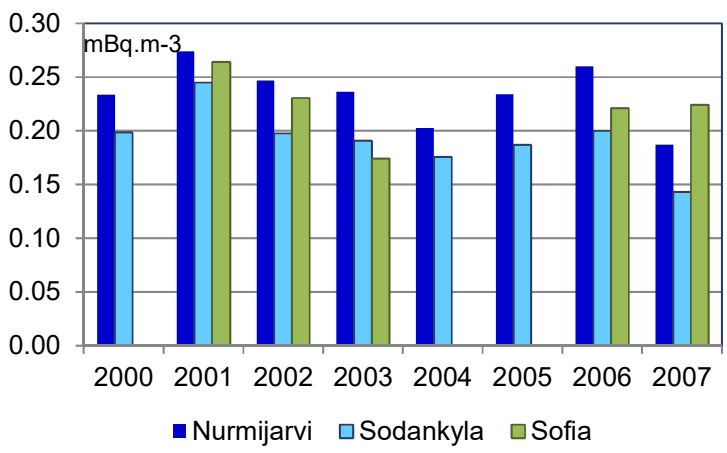

Figure 5. Lead-210 mean annual concentration in Finish stations and Sofia, 2000-2007

\subsection{First results of ${ }^{210} \mathrm{~Pb}$ in $P M_{10}$ fraction in Sofia}

The urban air pollution with $\mathrm{PM}_{10}$ is a serious problem in Bulgaria and in Sofia, in particular [20]. Therefore the use of specific elements and tracers as ${ }^{210} \mathrm{~Pb}$ can ensure additional information about composition and sources of $\mathrm{PM}_{10}$.

During the period 2012-2014 several seasonal field campaigns were organized in order to collect and analyze $\mathrm{PM}_{10}$ samples in the central meteorological observatory in Sofia [21]. The winter experiment in February 2012 is characterized with high $\mathrm{PM}_{10}$ mass and elemental concentrations variations and change in meteorological conditions. During the winter experiment in February 2012 the period from 6 to 25.02.2012 was characterized with cold and cloudy weather (the mean daily temperatures were below zero during the first 2 weeks). The daily mean relative humidity was in the range of $63-90 \%$ and low wind velocity and calm weather prevailed. It was snowing during the first two weeks and there was a stable snow cover during the sampling period with a maximum of $48 \mathrm{~cm}$ snow cover on 14.02. February 2012 was colder, $-3.4^{\circ} \mathrm{C}$ mean monthly value, then the multi-annual average (1961-1990).

The alpha counting methodology was tested and successfully applied for daily $\mathrm{PM}_{10}$ quartz filters with 1 sigma uncertainty of $\leq 20 \%$. Lead-210 daily concentration is compared to the $\mathrm{PM}_{10}$ mass concentration and elemental lead concentration, determined by EDXRF technique [9]. ${ }^{210} \mathrm{~Pb}$, elemental lead and $\mathrm{PM}_{10}$ mass concentration reveal different time variation for days with cyclonic weather and mass transport from south-west (06.02 and 13.02) and an anticyclone episode with a day to day increase in the $\mathrm{PM}_{10}$, ${ }^{210} \mathrm{~Pb}$ and lead concentrations. The precipitations which occurred on February 6 and 7 decreased the $\mathrm{PM}_{10}$ concentration significantly during the next days, but affected ${ }^{210} \mathrm{~Pb}$ concentration less. The results for ${ }^{210} \mathrm{~Pb}$ in $\mathrm{PM}_{10}$ particulate matter, collected in February 2012 in Sofia are given in Table 2.

Table 2. $\mathrm{PM}_{10},{ }^{210} \mathrm{~Pb}$ and concentration and ${ }^{210} \mathrm{~Pb} / \mathrm{PM}_{10}$ in Sofia, February 2012

\begin{tabular}{|c|c|c|c|}
\hline $\begin{array}{c}\text { Start date } \\
\text { of 24 h } \\
\text { sampling }\end{array}$ & $\begin{array}{c}\mathrm{PM}_{10} \\
\mu \mathrm{g} \cdot \mathrm{m}^{-3}\end{array}$ & $\begin{array}{c}{ }^{210} \mathrm{~Pb} \\
\mu \mathrm{Bq} . \mathrm{m}^{-3}\end{array}$ & $\begin{array}{c}210 \mathrm{~Pb} / \\
\mathrm{PM}_{10} \\
\mathrm{~Bq} / \mathrm{g}\end{array}$ \\
\hline O6.2.2012 & 63.6 & $1632 \pm 103$ & $25 \cdot 7$ \\
07.2 .2012 & 28.9 & $1012 \pm 81$ & 35.1 \\
08.2 .2012 & 31.4 & $1014 \pm 81$ & 32.3 \\
09.2 .2012 & 29.7 & $935 \pm 78$ & 31.4 \\
13.2 .2012 & 63.0 & $1170 \pm 87$ & 18.6 \\
14.2 .2012 & 75.8 & $623 \pm 64$ & 8.2 \\
15.2 .2012 & 93.6 & $467 \pm 55$ & 5.0 \\
16.2 .2012 & 23.1 & $311 \pm 45$ & 13.5 \\
17.2 .2012 & 38.6 & $312 \pm 45$ & 8.1 \\
18.2 .2012 & 25.8 & $157 \pm 32$ & 6.1 \\
19.2 .2012 & 87.3 & $79 \pm 23$ & 0.9 \\
20.2 .2012 & 158.8 & $467 \pm 55$ & 2.9 \\
21.2 .2012 & 160.1 & $623 \pm 64$ & 3.9 \\
22.2 .2012 & 98.3 & $857 \pm 75$ & 8.7 \\
Mean & 69.9 & 689.9 & 14.3 \\
Stan. Dev & 46.2 & 435.7 & 11.6 \\
\hline
\end{tabular}


High variability is registered in ${ }^{210} \mathrm{~Pb}$ daily values: from 0.078 to $1.632 \mathrm{mBq} \cdot \mathrm{m}^{-3}$ (Fig. 6). This range is close to the reported for the summer season by [4] for 3 stations from South-western Spain for the period 2004-2010. The ${ }^{210} \mathrm{~Pb}$ activity in $\mathrm{PM}_{10}$ urban site (Kanpur, India), reported in [22] varied from 0.50 to $4.8 \mathrm{mBq} \mathrm{m}-3$ during the period (January 2007-April 2009).

The $\mathrm{PM}_{10}$ mass and lead concentrations increased when the stagnant mixing conditions in the Atmospheric boundary layer (ABL) are observed, as for the period of strong anticyclone cold weather, 1922.02.2012 for example. There is some increase in ${ }^{210} \mathrm{~Pb}$ concentration from $17-18.02$ to 22.02 but not so strong because snow cover of and low temperatures in Sofia valley in February 2012 decreased ${ }^{222} \mathrm{Rn}$ exhalation and local ${ }^{210} \mathrm{~Pb}$ formation.

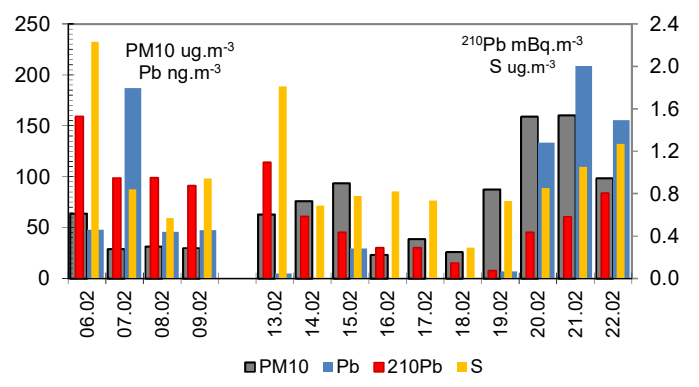

Figure 6. $\mathrm{PM}_{10}$ mass, ${ }^{210} \mathrm{~Pb}$, lead and sulfur concentrations in Sofia, February 2012

The ratio ${ }^{210} \mathrm{~Pb} / \mathrm{PM}_{10}$ can be used to estimate sources of $\mathrm{PM}_{10}$ pollution [23]. It varies in this case of Sofia from less than 0.9 in case of calm weather and prolonged inversion over the snow cover ground (2022.02.2012) up to $35 \mathrm{~Bq}{ }^{210} \mathrm{~Pb}$ per $\mathrm{g}$ of $\mathrm{PM}_{10}$ during the period 6-9.02.2012 when advection of air masses and snow precipitation occurred. The ${ }^{210} \mathrm{~Pb} / \mathrm{PM}_{10}$ ratio reported in [23] is characterized with winter maximum and summer minimum and within the range of less than 0.005 to more than $0.040 \mathrm{mBq}{ }^{210} \mathrm{~Pb}$ per $\mu \mathrm{g}$ of $\mathrm{PM}_{10}($ or $<5$ to $>40 \mathrm{~Bq} / \mathrm{g})$

Lead-210 is long-range transported. Thus, the decrease in the ${ }^{210} \mathrm{~Pb} / \mathrm{PM}_{10}$ ratio in stable winter conditions indicates the local sources of a particulate mass. It is interesting to note that a secondary pollutant, sulphate (presented in Fig.6 as S) has high concentration in the period of cyclonic air mass transport on 6 and 13 of February.

Environmental contamination due to anthropogenic lead emissions has been a serious issue globally. The use of leaded gasoline, industrial emissions and household waste incineration has caused huge lead emissions to the atmosphere in the past. For example, in downtown Helsinki stable lead concentrations between 227 and 3460 ng.m ${ }^{-3}$ were observed in 1970 [24]. The anthropogenic lead emissions have also had an impact on the specific activity of ${ }^{210} \mathrm{~Pb}$; in other words, the activity concentration of ${ }^{210} \mathrm{~Pb}$ divided by the concentration of stable lead in an environmental sample matrix. Lead originating from mines usually has low ${ }^{210} \mathrm{~Pb}$ content and, therefore, anthropogenic lead emissions, especially the local ones, tend to decrease the specific activity of ${ }^{210} \mathrm{~Pb}$ in the atmosphere. The specific activity observed in this study varied between 3.0 and 254 $\mathrm{kBq} \cdot \mathrm{g}^{-1} \mathrm{~Pb}$. In [25] it is reported that the specific activity of ${ }^{210} \mathrm{~Pb}$ in lichen in Sweden was relatively constant from the 1880 s onwards, about $74 \mathrm{kBq} . \mathrm{g}^{-1} \mathrm{~Pb}$, but after the World War II the specific activity of $210 \mathrm{~Pb}$ decreased to a level of about $22 \mathrm{kBq} \cdot \mathrm{g}^{-1} \mathrm{~Pb}$. The specific activity of ${ }^{210} \mathrm{~Pb}$ in aerosol particles in $1969-1970$ varied from 0.67 to $39 \mathrm{kBq} \cdot \mathrm{g}^{-1} \mathrm{~Pb}$ in southern Finland and from 3.9 to $91 \mathrm{kBq} \cdot \mathrm{g}^{-1} \mathrm{~Pb}$ in Northern Finland [26]. In 2006-2007, the specific activity of ${ }^{210} \mathrm{~Pb}$ in precipitation in Finland varied between 17 and 607 kBq.g ${ }^{-1} \mathrm{~Pb}$ with minimum values in winter, due to increased lead emissions from energy production during the cold season [27].

\section{CONCLUSIONS}

Collaboration established on the field of atmospheric radioactivity between FMI and NIMH provided an opportunity to obtain the results of ${ }^{210} \mathrm{~Pb}$ concentration in Bulgarian TSP and $\mathrm{PM}_{10}$ samples.

The results concerning the trends of ${ }^{210} \mathrm{~Pb}$ activity concentration in the total suspended particulate matter (TSP) in the ground-level air in Bulgaria and Finland, reported previously, are expanded with additional data Seasonal pattern is compared.

The first results for the ${ }^{210} \mathrm{~Pb}$ concentration in $\mathrm{PM}_{10}$ filter samples from Sofia show high day-to-day variation. Lead-210, as well as the ratio of ${ }^{210} \mathrm{~Pb}$ to stable lead concentration, can be used as an important tracer in $\mathrm{PM}_{10}$ source impact estimation.

For future studies of ${ }^{210} \mathrm{PM}$ concentration in the air, it is appropriate to use $\mathrm{PM}_{10}$ fraction sampling with the recommended type of filters and certified sampler.

Acknowledgement: The travel grant received by B. Veleva in July 2013 by the Finnish Association for Protection, Rescue, Security and Safety is highly appreciated. Part of the reported results were obtained within the project BGo51POoo1/3.3-05-0001 "Science and business" Operational Programme "Human Resources" of the European Social Fund (No Do4-108/28.03.2014, Index MU-14-05/2014).

\section{REFERENCES}

1. "Sources, effects and risks of ionizing radiation: Annex A: Exposures from natural sources of radiation," United Nations Scientific Committee on the Effects of Atomic radiation, New York (NY), USA, Rep. 45(A/43/45), 1988.

Retrieved from:

http://www.unscear.org/docs/publications/1988/UNS CEAR 1988 Annex-A.pdf Retrieved on: Feb. 23, 2017

2. M. Baskaran, "Po-210 and $\mathrm{Pb}-210$ as atmospheric tracers and global atmospheric Pb-210 fallout: a Review," J. Environ. Radioact., vol. 102, no. 5, pp. 500 - 513, May 2011.

DOI: 10.1016/j.jenvrad.2010.10.007

PMid: 21093126 
3. J. Paatero et al., "Lead-210 concentration in the air at Mt. Zeppelin, Ny-Ålesund, Svalbard,” Phys. Chem. Earth, vol. 28, no. 28-32, pp. 1175 - 1180, 2003. DOI: $10.1016 /$ j.pce.2003.08.050

4. R. L. Lozano et al., "Depositional fluxes and concentrations of $7 \mathrm{Be}$ and ${ }^{210} \mathrm{~Pb}$ in bulk precipitation and aerosols at the interface of Atlantic and Mediterranean coasts in Spain," J. Geophys. Res., vol. 116, no. D18, pp. D18213-1 - D18213-14, Sep. 2011. DOI: $10.1029 / 2011$ JD015675

5. N. A. Marley et al., "Measurement of ${ }^{210} \mathrm{~Pb},{ }^{210} \mathrm{Po}$, and ${ }^{210} \mathrm{Bi}$ in Size-Fractionated Atmospheric Aerosols: An Estimate of Fine-Awrosol Residence Times," Aerosol sci. and Technol., vol. 32, no. 6, pp. 569-583, Jun. 2000.

DOI: $10.1080 / 027868200303489$

6. " $1^{\text {st }}$ international expert meeting on sources and measurements of natural radionuclides applied to climate and air quality studies," World Meteorological Organization Global Atmosphere Watch, Geneva, Switzerland, Rep. 155, 2004.

Retrieved from:

https://library.wmo.int/pmb ged/wmo-td 1201.pdf Retrieved on: Feb. 17, 2017

7. J. Paatero, B. Veleva, J. Hatakka, "Long-Term Trends of Lead-210 Concentrations in the Ground-Level Air in Finland and Bulgaria," in Global Environmental Change: Challenges to Science and Society in Southeastern Europe, V. Alexandrov, M. Felix Gajdusek, G. Knight, A. Yotova, Eds., Berlin, Germany: Springer Science, 2010, ch. 19, pp. $229-234$ DOI: 10.1007/978-90-481-8695-2 19

8. Handbook of radioactivity analyses, M. F. L'Annunziata, Ed., 3rd ed., Cambridge (MA), USA: Academic Press, 2012. DOI: 10.1016/B978-0-12-384873-4.00001-3

9. B. Veleva, E. Hristova, E. Nikolova, M. Kolarova, R. Valcheva, "Elemental composition of air particulate $\left(\mathrm{PM}_{10}\right)$ in Sofia by EDXRF techniques," Journal of Chemical Technology and Metallurgy, vol. 49, no. 2, pp. $163-169,2014$.

Retrieved from:

http://dl.uctm.edu/journal/node/j2014-

2/8.\%20E.\%20Hristova 163-169.pdf

Retrieved on: Feb. 17, 2017

10. R. Mattsson, J. Paatero and J. Hatakka, "Automatic Alpha/Beta Analyser for Air Filter Samples - Absolute Determination of Radon Progeny by Pseudocoincidence Techniques," Radiat. Prot. Dosim., vol. 63, no. 2, pp. 133 - 139, Jan. 1996.

DOI: 10.1093/oxfordjournals.rpd.a031520

11. J. Paatero et al., "Airborne total beta activity in Finland and Bulgaria 1961-2000," in Book of Extended Synopses, Vienna, Austria: International Atomic Energy Agency, 2007, pp. 267-268

12. B. Veleva, J. Paatero, J. Hatakka, "Variation of the total beta activity in the surface air layer in Finland and Bulgaria during the last decades,” Bul. J. Meteo. \& Hydro., vol. 16, no. 1, pp. $62-67,2011$.

13. J. Paatero, B. Veleva, J. Hatakka, E. Hristova, "Atmospheric radioactivity in Bulgaria and Finland following the Fukushima nuclear accident," in Proc. BALWOIS Int. Conference on water, climate and environment, Ohrid, Republic of Macedonia, 2012. Retrieved from: http://balwois.com/wpcontent/uploads/old_proc/242.pdf Retrieved on: Feb. 17, 2017

14. E. Brattich et al., "Processes controlling the seasonal variations in ${ }^{210} \mathrm{~Pb}$ and $7 \mathrm{Be}$ at the Mt.Cimone WMOGAW global station, Italy: a model analysis," Atmos. Chem. Physics, vol. 17, pp. 1061 - 1080, Jan. 2017. DOI: $10.5194 /$ acp-17-1061-2017
15. M. M. Janković, et al., "Temporal concentration changes of beryllium-7 and lead-210 in ground level air in Serbia," Hem. Ind., vol. 68, no. 1, pp. 83 - 88, 2014. DOI: 10.2298/HEMIND130320031J

16. A.S. Likuku, "Factors influencing ambient concentration of ${ }^{210} \mathrm{~Pb}$ and $7 \mathrm{Be}$ over the city of Edinburg (55.9 N, 03.2 W)," J. Environ. Radioact., vol. 87, no. 3, pp. 289 - 304, Feb. 2006.

DOI: 10.1016/j.jenvrad.2005.12.006

PMid: 16487632

17. J. Paatero, J. Hatakka, R. Mattsson and Y. Viisanen, "Analysis of Daily Lead-210 Air Concentrations in Finland, 1967-1996," Radiat. Prot. Dosim., vol. 77, no. 3, pp. 191 - 198, Jun. 1998

DOI: 10.1093/oxfordjournals.rpd.a032310

18. J. Paatero et al., "Long-term Variations of Lead-210 Concentrations in Ground-Level Air in Finland: Effects of the North-Atlantic Oscillation," in Proc. EUROTRAC-2 Symposium 2000, Berlin, Germany, 2000, pp. 322 - 324

19. R. Winkler and G. Rosner, "Seasonal and long-term variation of $210 \mathrm{~Pb}$ concentration in air, atmospheric deposition rate and total deposition velocity in south Germany," Sci. Total Environ., vol. 263, no. 1-3, pp. 57 -68, Dec. 2000.

DOI: 10.1016/Soo48-9697(00)oo666-5

20. Министерство на околната среда и водите. (2016) Национален доклад за състоянието и опазването на околната среда. (Ministry of Environment and Water. (2016). National Report on the Status and Protection of the Environment in the Republic of Bulgaria.)

Retrieved from:

http://eea.government.bg/bg/soer/2014/soer-bg2014.pdf

Retrieved on: Feb. 17, 2017

21. B. Veleva et al., "Statistical evaluation of elemental composition data of $\mathrm{PM}_{10}$ air particulate in Sofia," Intern. J. of Environment and Pollution, vol. 57, no. 34, pp. $175-188,2015$. DOI: 10.1504/IJEP.2015.074502

22. K. Ram and M. M. Sarin, "Atmospheric ${ }^{210} \mathrm{~Pb}$, ${ }^{210} \mathrm{Po}$ and ${ }^{210} \mathrm{Po} /{ }^{210} \mathrm{~Pb}$ activity ratio in urban aerosols: temporal variability and impact of biomass burning emission," Tellus $B$, vol. 64 , no. 1, pp. 17513-1 - 17513-11, Mar. 2012.

DOI: 10.3402/tellusb.v64io.17513

23. E. Bratticha, M.A. Hernández-Ceballosb, J. A. G. Orzac, J. P. Bolívard, L. Tosittia, "The western Mediterranean basin as an aged aerosols reservoir. Insights from an old-fashioned but efficient radiotracer," Atmospheric Environment, vol. 141, pp. $481-493$, Sep. 2016

DOI: 10.1016/j.atmosenv.2016.07.022

24. R. Mattsson and T. Jaakkola, "An analysis of Helsinki air 1962 to 1977 based on trace metals and radionuclides," Geophysica, vol. 16, no. 1, pp. 1 - 42, 1979.

Retrieved from:

http://www.geophysica.fi/pdf/geophysica $1979 \quad 16 \quad 1$ 001 mattsson.pdf

Retrieved on: Feb. 17, 2017

25. B. R. R. Persson, E. Holm, K. Lidén, "Radiolead (210 Pb) and stable lead in the lichen Cladonia Alpestris," Oikos, vol. 25, no. 2, pp. 140 - 147, 1974.

DOI: $10.2307 / 3543635$

26. P. Kauranen, J. K. Miettinen, "Specific Activity of $2{ }^{210} \mathrm{~Pb}$ in the Environment," Intern. J. Environ. Anal. Chem. vol. 3, no. 4, pp. $307-316,1974$

DOI: $10.1080 / 03067317408071091$

PMid: 4443155

27. J. Paatero et al., "Deposition of atmospheric ${ }^{210} \mathrm{~Pb}$ and total beta activity in Finland," Journal of 
J. Paatero et al., Measurements of lead-210 activity concentration..., Rad. Applic., 2017, 2, 2, 108-114

Radioanalytical and Nuclear Chemistry, vol. 303,

no. 3, pp. 2413 - 2420, Mar. 2015.

DOI: $10.1007 / \mathrm{s} 10967-014-3785-7$ 